\title{
13: 110163084-110171422
}

National Cancer Institute

\section{Source}

National Cancer Institute. 13:110163084-110171422. NCI Thesaurus. Code C45015.

Physical location of ING1_Gene 